2014-01-01

\title{
A record of fossil shallow-water whale falls from Italy
}

Danise, $S$

http://hdl.handle.net/10026.1/3330

10.1111/let.12054

Lethaia

All content in PEARL is protected by copyright law. Author manuscripts are made available in accordance with publisher policies. Please cite only the published version using the details provided on the item record or document. In the absence of an open licence (e.g. Creative Commons), permissions for further reuse of content should be sought from the publisher or author. 


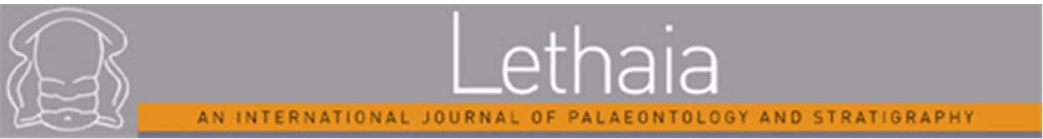

\section{Shallow-water fossil whale falls from the Neogene of Italy}

\begin{tabular}{|r|l|}
\hline Journal: & Lethaia \\
\hline Manuscript ID: & Draft \\
\hline Manuscript Type: & Original Article \\
\hline Date Submitted by the Author: & n/a \\
\hline Complete List of Authors: & $\begin{array}{l}\text { Danise, Silvia; Plymouth University, } \\
\text { Dominici, Stefano; Universita' degli Studi di Firenze, Museo di Storia } \\
\text { Naturale }\end{array}$ \\
\hline Keywords: & whale fall community, taphonomy, museum collection, Neogene, mollusc \\
\hline &
\end{tabular}


1 Shallow-water fossil whale falls from the Neogene of Italy

2 Silvia Danise, Stefano Dominici

\section{3 short title: Fossil shallow-water whale falls}

4

5 Twenty-five Neogene whales hosted in Italian museum collections and their associated fauna

6 were analysed for evidence of whale fall community development in shallow water settings.

7 Degree of bone articulation, completeness of the skeleton, and lithology of the embedding

8 sediments were used to gather information on relative water depth, water energy,

9 sedimentation rate and overall environmental predictability around the bones. Shark teeth and

10 hard shelled invertebrates with a necrophagous diet in close association with the bones were

11 used as evidence of scavenging. Fossil bone bioerosion, microbially-mediated cementation

12 and other mollusc shells in the proximity of the remains informed on past biological activity

13 around the bones.

14 The results are consistent with the hypothesis that shallow-water whale falls differ from their

15 deep-water counterparts. Taphonomic pathways are more variable on the shelf and whale

16 carcasses may not go through all steps of the ecological succession as recognized in the deep

17 sea. Whilst the mobile-scavenger and the enrichment opportunistic stages are well

18 represented, chemosynthetic taxa typical of the sulphophilic stage were recovered only in one

19 instance. The presence of a generalist fauna among the suspension feeding bivalves and

20 carnivore gastropods suggests that competitions rules out whale-fall specialists from shallow

21 shelf settings. 
23 Keywords: whale fall community; taphonomy; museum collection; Neogene; mollusc.

24

25 Silvia Danise [silvia.danise@gmail.com], School of Geography, Earth and Environmental

26 Sciences, Plymouth University, Drake Circus, Plymouth, PL4 8AA, UK. Previous address:

27 Dipartimento di Scienze della Terra, Università di Firenze, via La Pira 4, 50121, Firenze,

28 Italy

29 Stefano Dominici [stefano.dominici@unifi.it], Museo di Storia Naturale, Sezione di Geologia

30 e Paleontologia, Università di Firenze, via La Pira 4, 50121, Firenze, Italy 
32

\section{Introduction}

Whale fall communities are mostly known from deep water settings, where they pass through four stages of ecological succession and the whale organic matter is gradually consumed by a highly specialized fauna (Smith et al. 2002, Smith \& Baco 2003). During the "mobile scavenger" stage, which lasts months to years, sharks, hagfish and other scavenging organisms remove flesh and soft tissues. Polychaetes, crustaceans and other opportunistic small-sized animals thrive on organic remains during the subsequent "enrichment opportunist" stage, which can last months to years. In the "sulphophilic" stage a complex community, lasting for decades, relies on the hydrogen sulphide produced by microbial consumption of the lipid-rich bones. During this stage, chemosynthetic bacteria, free living or in symbiosis within vesicomyid clams, bathymodiolin mussels and vestimentiferan tube worms, are at the base of a food web where organic matter is primarily produced by the oxidation of inorganic compounds. In the "reef stage", occurring after the depletion of the whale organic material, the skeleton is colonized primarily by suspension feeders exploiting hard substrata and flow enhancement (Smith et al. 2002). Some of the animals found at whale falls are restricted to vertebrate carcasses, such as the gutless bone-eating worm Osedax (Rouse et al. 2004; 2011), whilst chemosynthetic taxa are shared with other deep-sea reducing habitats, like hydrothermal vents and hydrocarbon seeps (Smith et al. 1989; Smith \& Baco 2003; Dubilier et al. 2008).

Differently from the deep sea. on the shelf the sea floor is much more naturally enriched in organic carbon so that the organic input given by a whale carcass may represent an insignificant contribution to the nutrient budgets; taphonomic pathways are more complex than in the deep sea; and natural whale falls extremely rare (Smith 2006). Apart from anecdotal knowledge from rare natural occurrences (Smith 2006), modern data are available 
56 only from few experiments on artifically-sunken skeletons, performed so far in cold

57 temperate seas (Dahlgren et al. 2006; Pavyluck et al. 2009; Glover et al. 2010). These studies

suggest that successional stages develop also in shallow waters, with some differences with

respect to the deep sea. In general, the carcasses are consumed by generalist mobile

scavengers commonly living in the surrounding soft bottoms, and the rate of decomposition,

61 expressed in terms of time taken to remove all the flesh, is significantly slower compared to

62 deep-water analogues (Glover et al. 2010). The siboglinid worm Osedax is found also at

63 shallow water whale falls (Glover et al. 2005; Dahlgren et al. 2006), as well as

chemosymbiotic bivalves, although they are only known from rare reports not focusing on

whale fall ecosystems (Marshall 1900; Wàren 1991) and from a recent study from an artificially implanted carcass in the North Sea (Danise et al. in press).

Similarly to marine biologists, palaeontologists have also been more focused on the evolution of deep sea chemosymbiotic ecosystems, especially molluscs. As a consequence, most of the published paleontological papers deal with deep water whale falls (Squires et al. 1991; Goedert et al. 1995; Amano \& Little 2005; Nesbitt 2005; Kiel \& Goedert 2006; Amano et al. 2007; Pyenson \& Haasl 2007), with only a few exceptions (Dominici et al. 2009; Esperante et al. 2009; Danise et al. 2010).

Starting with the pioneering work of Schäfer (1972), palaeontologists working with large marine vertebrates have long shown interest on the serial biostratinomic processes that precede the final burial of the carcasses (Kauffman 1981; Martill 1985; 1987; Lancaster 1986), with a renewed interest after hearing the news from marine biologists, and proposing modern whale falls as viable analogues for the fossil record of Mesozoic reptiles (Hogler 1994; Martill et al. 1995; Reisdorf et al. 2012). Data collected during the excavation and recovery of a Pliocene fossil whale fall, at Orciano Pisano, Italy (Dominici et al. 2009), suggest that the taphonomic analysis of fossil marine vertebrates and their associated fauna 
81 can bring insights to the understanding of physical and biological processes at whale falls on

82 a time scale not available in modern time series studies, and from the less known shallow 83 environmental setting.

84 Fossil cetaceans are abundant in Neogene shallow marine sediments of Italy, 85 particularly in the central and northern regions of Piedmont, Emilia Romagna and Tuscany 86 (Bianucci \& Landini 2005; Bisconti 2009). Museum collections host specimens excavated 87 from the $19^{\text {th }}$ century, and for many of them information on the stratigraphic and taphonomic 88 settings at the excavation sites is available (Cortesi 1819; Capellini 1865; Strobel 1881; Portis 89 1885; Caretto 1970; Sarti \& Gasparri 1996; Chicchi \& Scacchetti 2001). Notwithstanding not 90 all the taphonomical data that can be gathered following a modern approach in the excavation 91 of large fossil vertebrates are available when studying museum specimens, some useful 92 information can be obtained. Different degrees of bone articulation, completeness of the 93 skeleton, and lithology of the embedding sediments can give information on water depth, 94 current intensity and rate of burial of the bones (Martill 1985; 1987; Lancaster 1986; Allison 95 et al. 1991). Shark teeth in close association with the bones, which past researchers seem to 96 have not missed (Bianucci et al. 2002), and hard shelled invertebrates with a necrophagous 97 diet, occasionally reported in past excavations, testify scavenging. Fossil bone bioerosion, 98 cementation, and hard shelled organisms in the proximity of the remains can inform on past 99 biological activity around the bones at the micro and mesoscale (Martill 1987; Allison et al. 100 1991).

101 Building on the experience by Dominici et al. (2009), we propose here the analysis of 102 twenty-five large fossil mysticetes hosted in northern and central Italian museum collections 103 with the aim of aim of (i) reconstructing the course of whale-fall ecological succession in 104 shallow water settings, and (ii) comparing it with modern and fossil data available from deep 105 water whale fall communities. 
107 Geological setting

108 The twenty-five fossil mysticetes here under study (W1-W25, Table 1) come from two 109 different paleogeographic domains of the Italian peninsula, the paleo-Adriatic and the paleo110 Tyrrhenian domain, both related to the tectonic evolution of the northern Apennines. The 111 northern Apennine fold-thrust belt was formed by collision between the European plate 112 (Corsica-Sardinia block) and the Adriatic microplate (related to the African plate). The thrust 113 imbrication includes the formation of an Upper Cretaceous-Cenozoic polyphase accretionary 114 wedge characterized by the migration of the foredeep depocenters towards the foreland, 115 actually located in the Adriatic Sea. Successively, during the Neogene, the Apennine thrust 116 belt was interested by a NNE-migrating pattern, with a compressional regime in the front of 117 the chain (palaeo-Adriatic domain) and extension in the hinterland area (palaeo-Tyrrhenian 118 domain) (Carmignani et al. 2001).

119 Specimens W2-W4 belong to the Pliocene Asti Basin, the North-Western extension of 120 the paleo-Adriatic sea (Fig. 1). The basin is filled by a regressive sedimentary succession of 121 circalitoral mudstones of Zanclean age at the base, followed by Piacentian shallow-marine 122 sandstones (Ferrero \& Pavia 1996; Polino \& Clari 2003). Specimens W5-W16 come from the 123 Pliocene portion of late Eocene to early Pleistocene satellite basins cropping out in the 124 northern Apennines. These satellite, piggy-back basins are mostly filled by terrigenous, 125 diachronuos deposits, originated during the NE migration of the Apennine thrust belt (Ricci 126 Lucchi 1987). In particular, specimens W5-W13 come from the Castell'Arquato basin, 127 whereas specimens W14-W16 are from the Pliocene Intra-Apenninic Basins of the Bologna 128 and Modena Apennines.

129 Specimens W1, W17-W24 belong to the Pliocene portion of Neogene hinterland basins 130 located on the Tyrrhenian side of the northern Apennines. They are part of the paleo- 
131 Tyrrhenian domain and originated in the internal portion of the chain, when important 132 extensional tectonic events were superposed upon existing compressional structures 133 (Carmignani et al. 2001). The sedimentary fill of Tyrrhenian basins typically consists of 134 Tortonian continental deposits at the base, covered by brackish, evaporitic, and marine 135 sediments of Messinian to Pleistocene age (Bossio et al. 1992).

136 The Miocene fossil whale (W25) comes from the early filling of piggy-back basins of 137 the Northern Apennines, belonging to the Epiligurid succession. It comes from the Monte 138 Vallassa Formation, which ranges in age from the Serravallian to the Tortonian, and is an 139 approximately $400 \mathrm{~m}$ thick sequence forming a marine transgressive cycle going from coastal 140 settings to inner and outer shelf deposits (Bellinzona et al. 1971).

\section{Materials and methods}

142 During the excavation and the museum preparation of the Orciano Pisano fossil whale 143 (W1) information on the taphonomy of the bones and the position of the associated 144 macrofauna respect to the whale skeleton were recorded (Dominici et al. 2009; Danise et al. 145 2010). To evaluate the level of generality of the Orciano Pisano finding, Italian Neogene 146 collections were surveyed for large more or less complete whale skeletons that could have 147 hosted a whale fall community ( $\mathrm{n}=25$, including W1; Table 1$)$. These include large skulls in 148 the absence of postcranial bones $(n=2)$ and articulated vertebral columns in the absence of the 149 skull $(n=3)$. We have not considered isolated bones, which were however abundant in some 150 collections. For each specimen information on the taphonomy of the fossil bones and on the 151 associated biota were collected (Table 2). Measured taphonomic data on the bones include (a) 152 articulation and (b) completeness of the skeleton; preservation of (c) cortical bones and (d) 153 vertebral processes; and (e) bone cementation. Information on the associated biota include the 154 presence/absence of (f) shark teeth, (g) chemosynthetic bivalves, (h) encrusting epibionts and 
155 (i) other invertebrates associated with the bones, identified at the highest taxonomic level 156 possible. Bone articulation was classified "high" when all the bones were preserved in 157 anatomical position, showing true bone-to-bone relationships with adjacent elements of the 158 skeleton; "medium" when the bones were slightly displaced from their original position and 159 the original skeleton outline was still recognizable; "low" when the skeletons were 160 completely disarticulated. Skeletal completes was classified "high" when all the main 161 constituent of the skeleton were recovered (skull, jaws, arms, ribs, vertebrae); "low" when 162 one or more skeletal element was missing. Cortical bone preservation was subdivided in 163 "high", "medium" or "low" if, respectively, the outer cortical bone was still in place, or it 164 was partially removed or absent. Vertebral processes preservation was classified "high" when 165 spinous processes were well preserved; "medium" when they were partially preserved; "low" 166 when they were absent. Cementation was considered "high" when large part of the skeleton 167 was enclosed in a carbonate concretion (e.g., the whole thoracic region); "medium" if 168 cements occurred in localized areas, otherwise "absent". Encrusting epibionts were recorded 169 if directly observed on the bone surface. Data on the presence/absence of shark teeth were 170 considered reliable, since these fossils particularly attracted palaeontologists during 171 excavations and have possibly never escaped recovery (see Bianucci et al. 2002). On the 172 other hand, the absence of chemosymbiotic bivalves and other invertebrates from museum 173 collections was interpreted as a missing datum (“n.d.”).

174 All these variables were recorded from different sources, including the direct 175 observation of museum specimens, literature data on the excavations, oral interviews to 176 people who directly participated to the digging operations. Additional data gathered from the 177 literature concerned the age and the taxonomical classification of each fossil whale and the 178 lithology of the embedding sediments. 
179

180

181

182

183

184

185

186

187

188

189

190

191

192

193

194

195

The studied fossil whales are hosted in the following museums: MGPT: Museo di Geologia e Paleontologia, Torino (TO); MPSC: Museo Paleontologico San Pietro in Consavia (AT); CMSNV: Civico Museo di Scienze Naturali di Voghera (PV), MPP: Museo Paleontologico Parmense (PR); MGC: Museo Geologico, Castell'Arquato (PC); MGCB: Museo "G. Capellini", Bologna (BO); MCRE: Musei Civici di Reggio Emilia (RE); MSNT: Museo di Storia Naturale e del Territorio, Università di Pisa, Calci (PI); MSNF: Museo di Storia Naturale, Firenze (FI); MCPG: Museo Civico di Palazzo Guicciardini, Montopoli in Valdarno (PI); CVB: Castello di Villa Banfi (SI); MCGA: Museo dei cicli geologici, Allerona (TR).

\section{Results}

\section{Taphonomy of twenty-five fossil whales}

The twenty-five analysed specimens come from sandy sediments (52\%) and mudstones (48\%). $28 \%$ are fully articulated skeletons, $24 \%$ have the bones slightly displaced from their original position, $36 \%$ are disarticulated, and for the others $(12 \%)$ no data are available (Fig. $2 \mathrm{~A}, 4)$. Most of the disarticulated skeletons were embedded in sandstones $(67 \%)$, and the others in mudstones. Well-articulated specimens come from sandstones in the $43 \%$ of the cases (Fig. 3A). In W22, which is a highly disarticulated skeleton, a bivariate orientation of the bones is observed (Fig. 4D). The specimen comes from a stratigraphic level characterized by silty sandstones and lay on a shell bed characterized by disarticulated and nestling bivalves which indicate reworking by bottom currents.

Half of the fossil skeletons are complete (Fig. 2A). Among incomplete skeletons four are acephalous, and two conserve only the skull (Table 1). 67\% of low articulated specimens 
202 are also incomplete; whereas most of the well-articulated skeletons (86\%) have a high degree 203 of completeness (Fig. 3B).

204 More than half of the specimens preserve the external cortical bone tissue (60\%), which 205 is partially preserved or absent in the remaining $36 \%$ (Fig. 2A). Vertebral processes are 206 pristine in the $32 \%$ of the fossil whales, partially damaged in the $24 \%$, totally absent in the $20720 \%$, whereas there are no available data in the $24 \%$ (Fig. 2A, 5A-C).

The $20 \%$ of the studied specimens are highly cemented (Fig. 2A). The thoracic region, 209 which includes cervical and thoracic vertebrae and the ribs, is the most interested by 210 cementation (Fig. 5D). Highly cemented specimens have in most of the cases a good degree 211 of cortical bone preservation (80\%, Fig. 3D) and most of them come from muddy sediments. 212 A medium degree of cementation was observed in the $36 \%$ of the specimens (e.g., specimen 213 in Fig. 5E, where isolated ribs are cemented). The others shows no cementation or no data are 214 available (Fig. 2A).

Shark teeth associated with fossil bones are documented for the $40 \%$ of the studied 216 fossil whales (40\%) (Fig. 2B). They more frequently come from articulated skeletons (Fig. 217 3C). They are found directly in contact with the bones, as in W1 (see Fig. 1F in Dominici et 218 al. 2009), or in the nearest sediments (Fig. 6A). The identified species are Carcharodon 219 Charcarias (W1, W15, W17, W22), Prionace glauca (W1), Carcharinus cf. brachyurus 220 (W22), Odontapsis sp. (W17), Isurus oxyrhyncus (W3), Galeorhinus galeus (W7), and 221 Galeorhinus cf. galeus (W15).

Cemented epibionts directly attached to the external surface of the bones were found on 223 the $44 \%$ of the specimens (Fig. 2B). They consist mostly of Ostrea specimens, with shells up 224 to $10 \mathrm{~cm}$ in length (Fig. 6C-D), and balanid barbacles, solitary (Fig. 6B) or in clusters (Fig. 225 6E). Bioencrustation was recovered both from specimens from sandy and muddy sediments. 
226

227

228

229

230

231

232

233

234

235

236

237

238

239

240

241

242

243

244

245

246

247

248

249

No data are available for chemosymbiotic bivalves associated with the fossil bones, except for W1 (Fig. 2A, 6F), where more than twenty lucinids of the species Megaxinus cf. incrassatus were found directly in contact with the bones (Dominici et al. 2009) together with two small specimens of the bathymodiolin mussel Idas sp. (Danise et al. 2010). Other invertebrates were recovered in the $40 \%$ of the cases (Fig. 2B). In most cases data are available only on molluscs, but decapods are also reported (see W16 and W17, Table 1). Within the molluscs the most represented trophic category is the suspension feeders, including bivalves of the family Glossidae, Pectinidae, Veneridae and Mytilidae (Fig. 7, Table 1). Tens of specimens of Glossus humanus were found in life position next to intervertebral disks of W8 (Fig. 7A), and a few large specimens in contact with W1 bones (Dominici et al. 2009). Pectinids were associated with specimens W3, W5, W17, W20 and W21, and are represented by the species Amusium cristatum, Chlamys opercularis and Chlamys cf. varia (Fig. 7D). The venerid Pelecyora brocchi is associated with specimens W15 (Fig. 7C) and W24 (Fig. 7E). Unidentified mytilids are associated with W5 and W21, Mytilus sp. with W14 and Modiolus sp. with W16. Deposit feeders were found at W3 (Aporrhais uttingeriana, Tellina compressa) and W17 (Aporrhais uttingeriana, Dentalium fossile). Predatory carnivores are represented by naticid gastropods at W5, W15 and W20 (Fig. 6E, 7E), and by Ficus sp. (W14, Table 1). Among scavenging gastropods, nassarids were frequent (Nassarius spp.: W1; W3; W20).

\section{Discussion}

\section{Biostratinomy of shelf-depth fossil whales}

Since water depth correlates with several environmental parameters that are also factors controlling biostratinomic processes, such as bottom energy and sedimentation rate, water 
250 depth was roughly estimated from grain size of the sediments associated with the fossil 251 whales. Muddy sediments settle in fact, on average, at greater depth than sandy sediments 252 (Thorson 1957). According to this general rule, fossil whales excavated from sandstones 253 were considered to come from shallower waters than those recovered from mudstones. A 254 positive correlation between lithology and degree of skeletal articulation was observed (Fig. $2553 \mathrm{~A}$ ), so that well-articulated specimens occur more frequently in muddy sediments, whereas 256 disarticulated in sandstones, as also observed in a similar study on Jurassic marine vertebrates 257 in the Lower Oxford Clay of central England (Martill 1985). This is consistent with 258 conditions of lower bottom energy in the deposition of mudstones with respect to that of 259 sandstones. As a consequence, in offshore areas with soft substrates and lower sedimentation 260 rate marine vertebrate skeletons are preserved preferentially more articulated than in onshore 261 position, where reworking before the final burial occurs more frequently.

From actualistic data is also known that disarticulation, especially if related to skeletal incompleteness, can be linked to carcass flotation after resurfacing (Allison et al. 1991). In shallow waters, floating carcasses resurfaced by the production of decay gasses in the abdominal cavity and within tissues, continue to decay. The removal of supportive soft tissues promotes the disarticulation of skeletal elements, so that the skull is usually the first part to be lost, and the mandibles are soon separated from the cranium (Schäfer 1972). Flotation in shallow waters may be prevented by scavenging if soft parts are stripped before 269 decay, or by catastrophic burial, if a sufficient overburden of sediment is deposited on the 270 carcass (Allison et al. 1991). Six of the fossil whales here under study, which miss either the trunk or the head, are good candidates as cases of re-flotation before final settling.

272 In cemented specimens, carbonate concretions probably precipitated by microbial 273 processes linked to the decay of the whale organic matter, which favours carbonate 274 precipitation increasing poor fluid alkalinity (Coleman \& Raiswell 1993). Carbonate cements 
275 may form during early diagenetic processes when the bones are still close to the sediment276 water interface (W25: Danise et al. 2013) or during late diagenetic processes (Kiel 2008). In 277 both of these circumstances they serve as an indirect evidence of rapid burial, which covered 278 the bones before all the organic matter was consumed. This is supported by the correlation 279 between the degree of cementation and cortical bone preservation: highly cemented 280 specimens show less signs of bone degradation that non-cemented once (Fig. 3D).

281 The abundance and diversity of shark teeth in close association with the bones indicates 282 an interaction between pelagic sharks and whales. In the modern Mediterranean, cetaceans 283 represent a significant component of the diet of large size white sharks, either through 284 scavenging or predation on living animals (Mojetta et al. 1997). Considering the body size of 285 Pliocene white sharks, Bianucci et al. (2002) hypothesized that active predation was possible 286 only on small Mysticeti, as some cetotheriids and baleanids (eg., Balaenula), whereas in all 287 other instances concerning larger specimens, the association with shark teeth must have been 288 true scavenging. In the present dataset shark teeth are all associated with large specimens (7$28910 \mathrm{~m}$ long), which can be considered positive evidence for scavenging. The correlation 290 between high degree of articulation and occurrence of shark teeth (Fig. 3C) suggests that in 291 shallow waters the action of scavengers is not intense enough to disarticulate whale carcasses 292 and disperse their bones. This datum is in accordance with what observed from a modern 293 shallow water study of a North Atlantic minke whale carcass at $125 \mathrm{~m}$ depth, which was 294 consumed by sharks and haghfishes within 6 months without significant disarticulation 295 (Dahlgren et al. 2006). It is important to note that no data are available on the presence and 296 importance of hagfishes as taphonomic agents in the Mediterranean, modern or ancient.

297 Low degree of preservation of the cortical bone tissue, together with the loss of 298 vertebral processes, suggest bioerosion both at the micro and mesoscale during exposition of 
299 the skeleton on the sea floor. At the microscale, bioerosion can be caused by heterotrophic 300 bacteria, cyanobacteria, algae or fungi consuming the bones (Amano \& Little 2005; Kiel 301 2008; Esperante et al. 2009; Shapiro \& Splanger 2009; Danise et al. 2013). Microscale 302 bioerosion so far has been mostly described by palaeontologists, and actualistic data are 303 needed to better know the metabolism and the nature of the trace makers. At the mesoscale, 304 an active bioeroder could have been the siboglinid worm Osedax, the most studied among 305 bone consumers in modern shallow and deep water whale falls (Glover et al. 2005; Braby et 306 al. 2007; Higgs et al. 2010), together with decapods, that can feed directly on fragile Osedax307 laden lateral processes (Braby et al. 2007). Decapods are also among the more active 308 scavengers at shallow sub-littoral, modern whale-fall sites (Glover et al. 2010) and are 309 reported from three sites in our survey (W1, W16 and W17). Osedax trace fossils have been 310 recognized so far in Oligocene whale and fish bones (Kiel et al. 2010; 2012) and in one 311 isolated Pliocene whale bone from Orciano Pisano, from an ancient collection housed at the 312 MSNF (Higgs et al. 2012).

313 Encrusting epifauna on the bones, especially oysters and balanids, are a good 314 paleoecological indicator for oxygenated bottom waters and low sedimentation rates, 315 depending on their size and concentration (Martill 1985). Lack of correlation between 316 bioencrustation and lithology in our dataset, does not help to relate biological and physical 317 processes. Instead, a one by one analysis of well-known encrusted skeletons and their 318 associated sedimentary features, allows some important considerations. At W1 only one 319 oyster was found attached to the bones, but the occurrence of other vertebrate remains in the 320 same outcrop, of a laterally continuous shell bed and glauconite grains are all evidence of low 321 sedimentation rates (Danise 2010). Many encrusting oysters and a lateral continuous shell 322 bed are also associated with W16. This shell bed is in the middle part of a small-scale 323 depositional sequence, corresponding to the maximum flooding interval (Danise 2010), 
324 thence also this case points to low sedimentation rate at the whale carcass. Scanty data are 325 available for the highly encrusted W14. Finally, the excellent report of Giuseppe Cortesi, 326 despite the whale skeleton is no longer available (W7), leaves little doubt that the whale 327 carcass he studied in the early nineteenth century had been deposited at a starved bottom: “... 328 picciole ostriche, parecchie delle quali veggonsi tuttavia incollate sulle ossa medesime... 329 Morì questo cetaceo in un mare permanente e tranquillo; e perciò rimase lo scheletro nella 330 sua naturale disposizione" ("many small oysters are still attached to the bones... This 331 cetacean has died in a calm sea bottom, thence the skeleton has maintained its natural 332 articulation": Cortesi 1819). Finally the size of the ostreids attached to the studied whales, up 333 to $10 \mathrm{~cm}$ long, suggests that some specimens lay on the sea floor at least for 6-10 years (see 334 Richardson 1993).

335 All of the above information helps framing the paucity of data concerning the 336 chemosynthetic bivalves. As a conservative assumption positive conclusions cannot be drawn 337 based on negative evidences. To this it must be added that chemosynthetic bivalves could 338 have been present but overlooked during excavations aimed at freeing the whale skeleton 339 from entombing sediments. Finally, very small chemosynthetic bivalves like 340 Bathymodiolinae, which can only be observed under a binocular microscope (e.g., Danise et 341 al. 2010), can be easily overlooked upon during excavations, when these are not expressly 342 designed at recovering the whole associated fauna. Nevertheless, large chemosynthetic 343 bivalves, like at W1, must have been originally lacking in the best described cases of a fossil 344 whale skeleton associated with molluscs (W3, W8, W14-W17), or they would have been 345 reported.

346 Among heterotrophic molluscs, the abundant suspension feeders were possibly 347 exploiting flow enhancement, similarly to encrusting epibionts mentioned in other instances 
348 (Martill 1986; Smith et al. 2002). Pectinids are the most frequent among suspension feeders

349 in our dataset, and are also found associated with shallow water artificially implanted 350 carcasses at 23-30 $\mathrm{m}$ in the North Sea (Glover et al. 2010). The unusual abundance or size of 351 Glossus humanus and its proximity to large bones at two sites (W1, W8) might point to its 352 special adaptation to high sulphide concentrations. However, the only available study on the 353 biology and diet of this taxon (Owen 1953), adapted to very soft and calm mud bottoms, does 354 not support this hypothesis. Nassaridae, found at three sites (W1, W3, W20), and abundant in 355 some cases, are scavengers that might have fed directly on the whale flesh, as observed in 356 modern examples (Glover et al. 2010). They could also have been secondarily active 357 predators on polychaetes and small crustaceans, as they are known to do in the present 358 (Britton \& Morton 1994). Naticidae and Ficidae gastropods are predatory active carnivores 359 present or abundant at many whale falls (W1, W5, W14, W15, W20); they could have preyed 360 on soft bodied biota living around the whale carcasses, or on bivalves and crustaceans (see 361 Taylor 1980).

\section{The fate of a whale carcass on the shelf}

363 Building on the recent experience of a fossil whale excavation aimed at recovering also 364 all of the associated fauna and record available taphonomic evidences (W1: Dominici et al. 365 2009), the present study has shown that also museum specimens can be used to understand 366 the taphonomy of shallow water whale falls and that insights bring substantial knowledge of 367 interest for both palaeontologists and marine biologists.Furthermore, given the now abundant 368 literature on the taphonomy of modern whales, the paleontological, ecosystem-level approach 369 seems a promising way to gather a richer understanding also of the taphonomy of Mesozoic 370 marine reptiles and other large marine vertebrates of the distant past.

371 Most of the natural occurrences of deep sea whale falls studied so far concern large and 372 well-articulated carcasses, which have undergone all stages of whale fall ecological 
373 succession, and have been or are inhabited by large-sized shelled specialists, suggesting very

374 similar taphonomic pathways (Allison et al. 1991; Naganuma et al. 1996; Goffredi et al.

375 2004; Lundsten et al. 2010). The ample variety of taphonomic states encountered in the

376 Italian Neogene whale record, and in other sparse instances (e.g., Esperante et al. 2009),

377 suggests instead that in shallow marine bottoms the destiny of whale carcasses can be more

378 variable than in the deep sea. Because of the wider ranges of variation of physical and

379 biological factors, the way carcasses are recycled on the shelf can vary to a large degree.

380 After a dead whale sinks, its permanence on the sea floor will depend on the interplay 381 between two main biological factors: the development of decompositional gasses and the rate 382 of scavenging (Allison et al. 1991). If the process of soft tissue degradation is dominated by 383 microbial decomposition and gas production, the carcass will easily resurface and become 384 dismembered, leading to the final settlement of incomplete specimens. This has occurred in a 385 minority of cases here under consideration, since the most studied specimens were complete 386 (complete specimen here include those lacking the rostrum or the neurocranium, but with the 387 two mandibles). This implies that most of the large whale falls analysed in this study that 388 have made it to the fossil record, passed through the intense activity of scavengers and the 389 rapid removal of abdominal soft tissues. Since gas production was not sufficient for 390 buoyancy, the carcass had remained on the bottom where it had landed. The following course 391 of transformation depended on sedimentation rates. Each carcass, whether complete or not, 392 might have been exposed on the sea floor, interacting with the local ecosystem and 393 subsequently becoming buried at any stage of development of a whale fall community.

Bioerosion and biota associated with the studied specimens suggest that most of them 395 underwent an intense and prolonged biotic activity. We could recognize both the mobile 396 scavenger stage and the enrichment opportunist stage on many shelf specimens, not differing 
397 from what occurs at deeper settings. Scavenging is testified by shark teeth or by shelled

398 predatory invertebrates and the opportunist stage by the general downgrading of the bones or

399 by rare traces of the bone-eating worm Osedax. Some specimens underwent a more 400 prolonged exposure, pointing to sediment starvation, as testified by cemented epifauna 401 resting on downgraded bones. The finding of bioincrustation on pristine bone suggests that 402 successional stages can be intermingled and that taphonomic pathways can be complex, 403 depending on the rapidity with which a part of the skeleton is exposed and for how long 404 before final burial.

405 Benthic taxa associated with the bones, mostly suspension feeding bivalves and 406 carnivore gastropods, are common elements of other Neogene marine associations. Among 407 these are the Pectinidae with their general adaptation to exploit enhanced flow conditions, 408 and the Nassaridae, feeding on large food particles. This suggests that competition can be a 409 possible factor ruling out whale-fall specialists from shallow shelf whale falls. The 410 sulphophilic stage of whale falls was recognized only in one case, which coincides with the 411 only excavation carried out so far on an ecosystem-level approach. Some evidences suggest 412 that this stage on the shelf seldom involves larger chemosymbiotic molluscs like in deep sea 413 sites. These evidences include (i) the only presence at the Orciano Pisano whale fall (W1) of 414 infaunal lucinids and very rare bathymodiolins (Dominici et al. 2009; Danise et al. 2010) and 415 the absence of other chemosymbiotic bivalves like vesicomyid clams; and (ii) the lack of 416 chemosymbiotic taxa among all other shelled benthic invertebrates reported at other sites.

\section{Conclusions}

418 The taphonomic analysis of twenty-five large fossil mysticetes from the Italian Neogene 419 gives new insights on the course of the whale fall ecological succession in shallow water 420 settings. 
421 (i) In shallow marine bottoms the destiny of whale carcasses can be more variable than in 422 the deep sea, and the ecological succession more irregular.

423 (ii) The mobile scavenger stage at shelf depths, testified by shark teeth and possibly by 424 shelled predatory invertebrates common around the bones of large specimens, is 425 similar to the mobile scavenger stage in deeper settings.

426 (iii) The enrichment opportunist stage is indirectly attested by the general downgrading of 427 the bones, exceptionally by traces of the bone-eating worm Osedax, and possibly 428 by predatory active carnivores that preyed on soft bodied biota living around the $429 \quad$ whale carcasses.

430 (iv) The sulphophilic stage was recognized in only one instance; this was not probably just 431 overlooked during the majority of past excavations, but it might have been $432 \quad$ altogether absent, especially at very shallow depths.

433 (v) The reef stage was testified by cemented epifauna resting on downgraded bones. 434 Bioincrustation on pristine bone suggests that successional stages can be 435 intermingled.

436 (vi) The presence of a generalist fauna among the suspension feeding bivalves and 437 carnivore gastropods suggests that competition is a possible factor ruling out $438 \quad$ whale-fall specialists from shallow shelf whale falls. 
440 References

441 Allison, P.A., Smith, C.R., Kukert, H., Deming, J.W. \& Bennett, B.A. 1991: Deep-

442 water taphonomy of vertebrate carcasses: a whale skeleton in the bathyal Santa Catalina 443 Basin. Paleobiology 17, 78-89.

444 Amano, K. \& Little, C.T.S. 2005: Miocene whale-fall community from Hokkaido, 445 northern Japan. Palaeogeography, Palaeoclimatology, Palaeoecology 215, 345-356.

446 Amano, K., Little, C.T.S. \& Inoue, K. 2007: A new Miocene whale-fall community 447 from Japan. Palaeogeography, Palaeoclimatology, Palaeoecology 247, 236-242.

448 Bellinzona. G., Boni. A., Braga,G. \& Marchetti, G. 1971: Note illustrative della Carta 449 Geologica d'Italia in scala 1:100.000, Foglio 71, Voghera. Servizio Geologico d'Italia, $450 \quad$ Roma, $121 \mathrm{pp}$.

Bianucci, G. \& Landini, W. 2005: I paleositi a vertebrati fossili della Provincia di Pisa. 452 Atti della Società Toscana di Scienze Naturali, Memorie, Serie A 110, 1-21.

453 Bianucci, G., Bisconti, M., Landini, W., Storai, T., Zuffa, M., Giuliani, S. \& Mojetta, 454 A. 2002: Mediterranean white shark-cetaceans interactions through time: a comparison 455 between Pliocene and Recent data. In Vacchi, M., La Mesa, G., Serena, F. \& Séret, B. (eds.): 456 Proceedings of the 4th European Elasmobranch Association Meeting, Livorno, ICRAM, 457 ARPAT \& SFI, 33-48.

458 Bisconti, M. 2002: An early Late Pliocene right whale (genus Eubalaena) from 459 Tuscany (Central Italy). Bollettino della Società Paleontologica Italiana 41, 83-91.

460 Bisconti, M. 2007: A new basal balaenoperid whale from the Pliocene of Northern 461 Italy. Palaeontology 50, 1103-1122. 
462

463

464

465

466

467

468

469

470

471

472

473

474

475

476

477

478

479

480

481

482

483

Bisconti, M. 2009: Taxonomy and evolution of the Italian Pliocene Mysticeti

(Mammalia, Cetacea): a state of the art. Bollettino della Società Paleontologica Italiana 48, $147-156$.

Borselli, V. \& Cozzini, F. 1992: Il recupero di un cetaceo fossile in località Ponte a Elsa (Pisa). Museologia Scientifica 8, 9-22.

Bossio, A., Cerri, R., Costantini, A., Gandin, A., Lazzarotto, A., Magi, M., Mazzanti, R., Mazzei, R., Sagri, M., Salvatorini, G. \& Sandrelli, F. 1992: I bacini distensivi neogenici e quaternari della Toscana. $76 a$ Riunione estiva Società Geolologica Italiana, Guida alle escursioni, 199-227.

Braby, C.E., Rouse, G.W., Johnson, S.B., Jones, W.J. \& Vrijenhoek, R.C. 2007: Bathymetric and temporal variation among Osedax boneworms and associated megafauna on whale-falls in Monterey Bay, California. Deep-Sea Research I 54, 1773-1791.

Britton, J.C. \& Morton, B. 1994: Marine carrion and scavengers. Oceanography and Marine Biology: An Annual Review 32, 369-434.

Capellini, G. 1865: Balenottere fossili del bolognese. Memorie della Regia Accademia delle Scienze dell'Istituto di Bologna 4, 3-24.

Capellini, G. 1905: Balene fossili toscane. III Idiocetus guicciardinii. Atti della Reale Accademia delle Scienze dell'Istituto di Bologna, Serie 68, 113-115.

Caretto, P.G. 1970: La balenottera delle sabbie plioceniche di Valmontasca (Vigliano d'Asti). Bollettino della Società Paleontologica Italiana 9, 3-75.

Carmignani, L., Decandia, F.A., Disperati, L., Fantozzi, P.L., Klingfield, R., Lazzarotto, A., Liotta, D. and Meccheri, M. 2001: Inner Northern Apennines. In Vai, G.B. \& 
484 Martini, I.P. (eds.): Anatomy of an Orogen: the Apennines and adjacent Mediterranean 485 basins. Springer press, 197-214.

486 Chicchi, S. \& Scacchetti, M. 2001: Valentina - Balena fossile del mare padano. Civici 487 Musei, Reggio Emilia, 31 pp.

488 Coleman, M.L. \& Raiswell, R. 1993: Microbial mineralization of organic matter: 489 mechanisms of self-organization and inferred rates of precipitation of diagenetic minerals. $490 \quad$ Philosophical Transactions: Physical Sciences and Engineering 344, 69-87.

491 Cortesi, G. 1819: Saggi geologici degli stati di Parma e Piacenza. Torchj del Majno, 492 Piacenza, $165 \mathrm{pp}$.

493 Dahlgren, T.G., Wiklund, H., Källström, B., Lundälv, T., Smith, C.R. \& Glover, A. 494 2006: A shallow-water whale-fall experiment in the north Atlantic. Cahiers de Biologie 495 Marine 47, 385-389.

496 Damarco, P. 1995: Una curiosa combinazione: la balena e le conchiglie fossili. Word 497 Shells 15, 26-28.

498 Danise, S. 2010. Modern and fossil shallow water whale fall communities. Unpublished $499 \mathrm{PhD}$, Universita' degli Studi di Firenze, Italy. 178 pp.

500 Danise, S., Dominici, S. \& Betocchi, U. 2010: Mollusk species at a Pliocene shelf 501 whale fall (Orciano Pisano, Tuscany). Palaios 25, 449-556.

502 Danise, S., Cavalazzi, B., Dominici, S., Westall, F., Monechi, S. \& Guioli, S. 2013:

503 Fossil microbial ecosystem associated with a Miocene shallow-water whale-fall from 504 Northern Italy. Palaeogeography, Palaeoclimatololgy, Palaeoecology 317-318, 13-26. 
505

506 507

508

509

510

511

512

Danise, S., Dominici, S., Dahlgren, T.G. \& Glover, A.G. (in press). Molluscs from a shallow-water whale-fall and their affinities with adjacent benthic communities on the Swedish west coast. Marine Biological Research.

Dominici, S., Cioppi, E., Danise, S., Betocchi, U., Gallai, G., Tangocci, F., Valleri, G. \& Monechi S. 2009: Mediterranean fossil whale falls and the adaptation of mollusks to extreme habitats. Geology 37, 815-818.

Dubilier, N., Bergin, C. \& Lott, C. 2008: Symbiotic diversity in marine animals: The art of harnessing chemosynthesis. Nature Review 6, 725-740.

Esperante, R., Muñiz Guinea, F. \& Nick, K.E. 2009: Taphonomy of a Mysticeti whale in the Lower Pliocene Huelva Sands Formation (Southern Spain). Geologica Acta 7, 489505.

Ferrero, E. \& Pavia, G. 1996: La successione marina pre-villafranchiana. In Carraro, F. (ed.): Revisione del Villafranchiano nell'area-tipo di Villafranca d'Asti. Il Quaternario 9, $36-38$.

Francou, C. 1994: Nelle terre del Piacenziano. Fondazione Cassa di Risparmio di Piacenza e Vigevano, Piacenza, 126 pp.

Glover, A.G., Kallstrom, B., Smith, C.R. \& Dahlgren, T.G. 2005: World-wide whale worms? A new species of Osedax from the shallow North Atlantic. Proceedings of the Royal Society of London B 272, 2587-2592.

Glover, A.G., Higgs, N.D., Bagley, P.M., Carlsson, R., Davies,A.G., Kemp, K.M., Last, K.S., Norling, K., Rosenberg, R., Wallin, K., Källström, B. \& Dahlgren, T.G. 2010: A 
526 live video observatory reveals temporal processes at a shelf-depth whale-fall. Cahiers de 527 Biologie Marine 51, 375-381.

528 Goedert, J.L., Squires, R.L. \& Barnes, L.G. 1995: Paleoecology of whale-fall habitats 529 from deep-water Oligocene rocks, Olympic Peninsula, Washington State. Palaeogeography, 530 Palaeoclimatology, Palaeoecology 118, 151-158.

531 Goffredi, S.K., Paull, C.K., Fulton-Bennett, K., Hurtado, L.A. \& Vrijenhoek, R.C. 532 2004: Unusual benthic fauna associated with a whale fall in Monterey Canyon, California. 533 Deep-Sea Research I 51, 1295-1306.

534 Higgs, N.D., Glover, A.G., Dahlgren, T.G.\& Little, C.T.S. 2010: Using computed535 tomography to document borings by Osedax mucofloris in whale bone. Cahiers de Marine 536 Biologie 51, 401-405.

Higgs, N.D., Little, C.T.S., Glover, A.G., Dahlgren, T.G., Smith, C.R. \& Dominici, S. 538 2012: Evidence of Osedax worm borings in Pliocene $(\sim 3 \mathrm{Ma})$ whale bone from the 539 Mediterranean. Historical Biology 24, 269-277.

540 Hogler, J.A. 1994: Speculations on the role of marine reptile deadfalls in Mesozoic 541 deep-sea paleoecology. Palaios 9, 42-47.

542 Kauffman, G. 1981: Ecological reappraisal of the German Posidonienscheifer 543 (Toarcian) and the stagnant basin model. In Gray J., Boucot A.J. \& Berryw .B.N. (eds.): 544 Communities of the Past. Hutchison Ross, Stoudsberg, Pennsylvania, 311-381.

545 Kiel, S. 2008: Fossil evidence for micro- and macrofaunal utilization of large 546 nektonfalls: examples from early Cenozoic deep-water sediments in Washington State, USA. 547 Palaeogeography, Palaeoclimatology, Palaeoecology 267, 161-174. 
548 Kiel, S. \& Goedert, J.L. 2006: Deep-sea food bonanzas: Early Cenozoic whale-fall 549 communities resemble wood-fall rather than seep communities. Proceedings of the Royal $550 \quad$ Society B 273, 2625-2631.

Kiel, S., Goedert, J.L., Kahl, W.-A. \& Rouse, G.W. 2010: Fossil traces of the bone552 eating worm Osedax in early Oligocene whale bones. Proceedings of the National Academy 553 of Science, USA 107, 8656-8659.

Kiel, S., Kahl, W.-A. \& Goedert, J.L. 2012: Traces of the bone-eating annelid Osedax 555 in Oligocene whale teeth and fish bones. Paläontologische Zeitschrift 87, 161-167.

556 Lancaster, W.C. 1986: The taphonomy of an archaeocete skeleton and its associated 557 fauna. Proceedings of GCAGS Symposium. Montgomery Landing Site, Marine Eocene of 558 central LA, 119-131.

559 Lundsten, L., Paull, C.K., Schlining, K.L., McGann, M. \& Ussler III, W. 2010: 560 Biological characterization of a whale-fall near Vancouver Island, British Columbia, Canada. 561 Deep Sea Research I 57, 918-922.

562 Marshall, J.T. 1900: On a Brtish species of Myrina, with a note on the genus Idas. 563 Journal of Malacology 7, 167-170.

564 Martill, D.M. 1985: The preservation of marine vertebrates in the Lower Oxford Clay 565 (Jurassic) of central England. Philosophical Transactions of the Royal Society B 311, 155566165.

Martill, D.M. 1987: A taphonomic and diagenetic case study of a partially articulated 568 ichthyosaur. Palaeontology 30, 543-555. 
569 Martill, D.M., Cruickshank, A.R.I. \& Taylor, M.A. 1995: Speculations on the role of 570 marine reptile deadfalls in Mesozoic deep-sea paleoecology: comment. Palaios 10, 96-97.

571 Mojetta, A., Storai, T. \& Zuffa, M. 1997: Segnalazioni di Carcharodon carcharias in 572 acque italiane. Quaderni della Civica Stazione Idrobiologica di Milano 22, 23-38.

573 Naganuma, T., Wada, H. \& Fujioka, K. 1996: Biological community and sediment fatty 574 acids associated with the deep-sea whale skeleton at the Torishima Seamount. Journal of 575 Oceanography 52, 1-15.

576 Nesbitt, E.A. 2005: A novel trophic relationship between cassid gastropods and 577 mysticete whale carcasses. Lethaia 38, 17-25.

578 Owen, G. 1953: On the biology of Glossus humanus (L.) (Isocardia cor Lam.). Journal 579 of the Marine Biology Associaiton, UK 32, 85-106.

580 Pavlyuk, O.N., Trebukhova, Y.A. \& Tarasov, V.G. 2009: The impact of implanted 581 whale carcass on Nematode communities in shallow water area of Peter the Great Bay (East 582 Sea). Ocean Science Journal 44, 181-188.

583 Polino, R. \& Clari, P.A. 2003: Carta Geologica d'Italia alla scala 1.50000, Foglio 157. 584 Torino, Apat Dipartimento Difesa del Suolo.

585 Portis, A. 1885: Catalogo descrittivo dei Talassoterii rinvenuti nei terreni terziari del 586 Piemonte e della Liguria. Memorie della Reale Accademia delle Scienze di Torino 37, 247587365.

588 Pyenson, N.D. \& Haasl, D.M. 2007: Miocene whale-fall from California demonstrates 589 that cetacean size did not determine the evolution of modern whale-fall communities. Biology $590 \quad$ Letters 3, 709-711. 
591

592

593

594

595

596

597

598

599

600

601

602

603

604

605

606

607

608

609

610

611

612 Palaeoecology 274, 196-203.

Sedimentary Geology 50, 119-134. 493-500. University of Chicago Press, 568 ppF.

Ricci Lucchi, F. 1987: Semi-allochthonous sedimentation in the Apenninic thrust belt.

Richardson, C.A., Collis, S.A., Ekaratne, K., Dare, P. \& Key, D. 1993: The age determination and growth rate of the European flat oyster, Ostrea edulis, in British waters determined from acetate peels of umbo growth lines. ICES Journal of Marine Science 50,

Rouse, G.W., Goffredi, S.K. \& Vrijenhoek, R.C. 2004: Osedax: Bone-eating marine worms with dwarf males. Science 305, 668-671.

Rouse, G.W., Goffredi, S.K., Johnson, S.B. \& Vrijenhoek, R.C. 2011: Not whale-fall specialists, Osedax worms also consume fish bones. Biology Letters 7, 736-739.

Sarti, C. \& Gasparri, F. 1996: La balenottera Pliocenica di Gorgognano (Pianoro, Bologna). Bollettino della Società Paleontologica Italiana 35, 331-347.

Scabelli, 1843: Di una balena, di un delfino e molte conchiglie cavate dai colli del piacentino. Tipografia vescovile tedeschi, Piacenza.

Schäfer, W. 1972: Ecology and palaeoecology of marine environments. Chicago,

Shapiro, R.S. \& Spangler, E. 2009: Bacterial fossil record in whale-falls: Petrographic evidence of microbial sulfate reduction. Palaeogeography, Palaeoclimatology, 
613 Smith, C.R. 2006: Bigger is better: The role of whales as detritus in marine ecosystems.

614 In Estes J. (ed.): Whales, Whaling and Ocean Ecosystems. Berkeley, University of California 615 Press, 284-299.

616 Smith, C.R. \& Baco, A.R. 2003: Ecology of whale falls at the deep-sea floor. 617 Oceanography and Marine Biology: an Annual Review 41, 311-354.

618 Smith, C.R., Kukert, H., Wheatcroft, R.A., Jumars, P.A. \& Deming, J.W. 1989: Vent 619 fauna on whale remains. Nature 341, 27-28.

620 Smith, C.R., Baco, A.R. \& Glover, A. 2002: Faunal succession on replicate deep-sea whale 621 falls: time scales and vent-seep affinities. Cahiers de Marine Biologie 43, 293-297.

622 Squires, R.L., Goedert, J.L. \& Barnes, L.G. 1991: Whale carcasses. Nature 349, 574.

623 Strobel, P. 1881. Iconografia comparata delle ossa fossili del gabinetto di Storia 624 Naturale dell’Università di Parma. Libreria Editrice Luigi Battei, Parma. 32 pp.

625 Taylor, J.D. 1980: Diets and habitats of shallow water predatory gastropods around 626 Tolo Channel, Hong Kong. In Morton B. (ed.): The Malacofauna of Hong Kong and 627 Southern China. Hong Kong University Press, Hong Kong, 163-180.

628 Thorson, G. 1957: Bottom communities (sublittoral or shallow shelf). Geological 629 Society of America, Memoir 67, 461-534.

630 Trevisan, L. 1941: Una nuova specie di Balaenula pliocenica. Palaeontographia Italica $63140,1-13$.

632 Vai, G.B. 2001: Structure and stratigraphy: an overview. In Vai, F. \& Martini, I.P. 633 (eds.): Anatomy of an Orogen: The Apennines and Adjacent Mediterranean Basins. Springer 634 press, 15-32. 
1

2

3

4

5

6

7

8

9

10

11

12

13

14

15

16

17

18

19

20

21

22

23

24

25

26

27

28

29

30

31

32

33

34

35

36

37

38

39

40

41

42

43

44

45

46

47

48

49

50

51

52

53

54

55

56

57

58

59

60
635 Warén, A. 1991: New and little known Mollusca from Iceland and Scandinavia. Sarsia

$63676,53-124$.

637 


\section{FIGURES}

639 Fig. 1. Schematic geological map with the localities of recovery of the studied fossil whales. 640 Modified from Vai (2001).

641 Fig. 2. Histograms summarizing results of the analyses on the twenty-five fossil whales. A. 642 Taphonomic data: bone articulation, skeletal completeness, cortical bone preservation, 643 vertebral process preservation, bone cementation. B. Biota associated with the bones: shark 644 teeth, chemosymbiotic bivalves, encrusting epifauna,, other invertebrates. All data expressed 645 in per cent. Error bars represent the standard error.

646 Fig. 3. Bar diagrams comparing some of the measured taphonomic and paleoecologic 647 variables. A. Degree of bone articulation versus lithology of the embedding sediments. B. 648 Bone articulation versus skeletal completeness. C. Bone articulation versus presence/absence 649 of shark teeth. D. Changes in degree of cementation versus cortical bone preservation. vs: 650 versus.

651 Fig. 4. Different degrees of skeletal articulation in the studied fossil whales. A. W10 with 652 highly articulated bones and well preserved vertebral processes. B. Acephalous W18 in sandy 653 sediments; ribs are in true position and vertebrae missing or displaced C. W16 in fine grained 654 silty sandstones, with a medium degree of bone articulation; note the ribs in anatomical 655 position whereas vertebrae are displaced. D. W22, highly disarticulated specimen; note the 656 bimodal distribution of the bones.

657 Fig. 5. Different degrees of cortical bone preservation, vertebral process preservation and 658 cementation. A. W1 with highly bioeroded vertebra and badly preserved compact bone tissue. 659 B. W13 with partially preserved spinous processes and partially preserved compact bone. C. 660 W11 with intact spinous processes and well preserved outer compact bone. D. Articulated 
661 skeleton with pristine costae, heavily cemented to thoracic vertebrae in unconsolidated muds 662 (W17). E. Isolated ribs partially enclosed in a carbonate concretion.

663 Fig. 6. Shark teeth, encrusting epifauna and chemosynthetic bivalves associated with fossil 664 whale bones. A. W17 with Carcharodon carcharias tooth next to the bones. B. Large solitary 665 balanid barnacle on one vertebral process (W22). C and D. Ribs and mandibles with 666 encrusting oysters (W16). E. W11 encrusted with balanid barnacles and a small naticid 667 gastropod next to them. F. Articulated specimen of the lucinid Megaxinus cf. incrassatus on 668 the skull of W1.

669 Fig. 7. Molluscs associated with fossil whale bones. A. Three articulated specimens of 670 Glossus humanus (arrows) next to intervertebral disks of a large whale (W8) embedded in 671 muddy sediments B. Mytilid on one vertebra (W11). C. Pelecyora brocchi ? attached to a 672 vertebra (W24). D. Mytilid (large arrow) and pectinid cf. Chlamys varia (small arrow) 673 enclosed in the carbonate concretion around W21. E. Pelecyora brocchi? (large arrow) and 674 naticid gastropod (small arrow) on lumbar vertebra (W15).

675 Table 1. Information on the studied Neogene fossil whales. Hosting institution abbreviation 676 and taphonomic variables explained in the text. Among incomplete skeletons, those with *are 677 acephalous, those with " preserve only the skull.

678 Table 2. List of the main taphonomic and paleoecologic variables considered in this study. 
II MID PLEISTOCENE TO HOLOCENEDEPOSITS. ... LATE MIOCENE TO PLEISTOCENE bAthạia

OLIGO-MIOCENE BASINS

W1

Page 32 of 42

LIGURIAN UNITS

TUSCAN UNITS

ПD UMBRIA-ROMAGNA UNITS

METAMORPHIC UNITS

2 MAGMATIC ROCKS

3 A MAJOR TRUST

$\because 4$

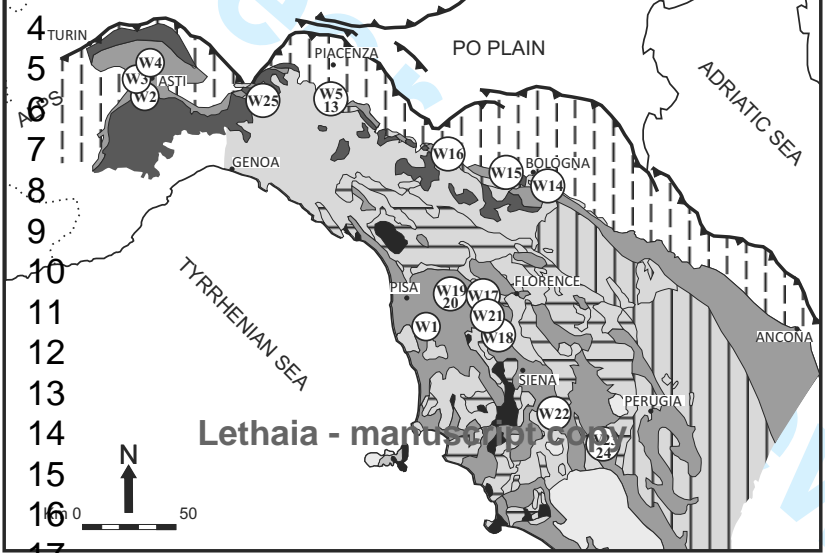




\section{A 33 of 42 TAPHONOMIC DATA \\ Page 33 of 42 TAPHONOMIC DATA}

\section{Lethaia}

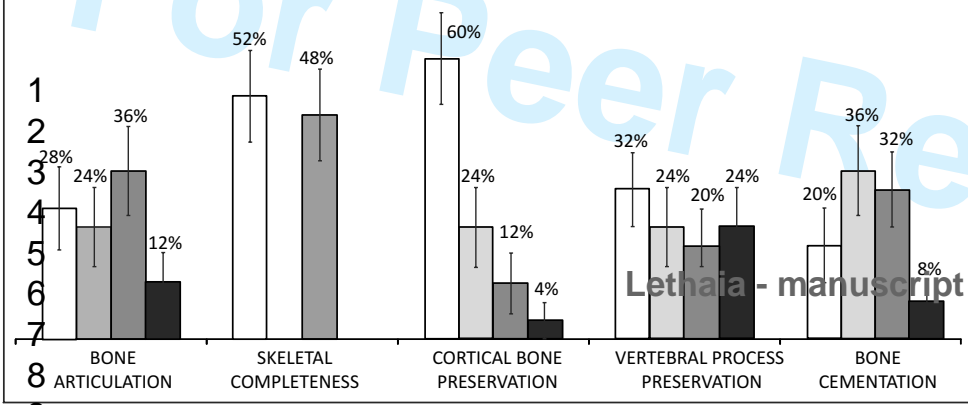

B ASSOCIATED BIOTA

$\square$ PRESENT $\square$ ABSENT $\square$ n.d.

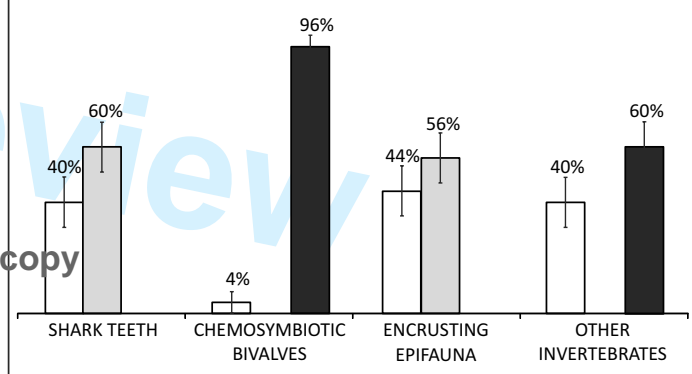




\section{A \\ A \\ ARTICULATION vS LITOLOGY}

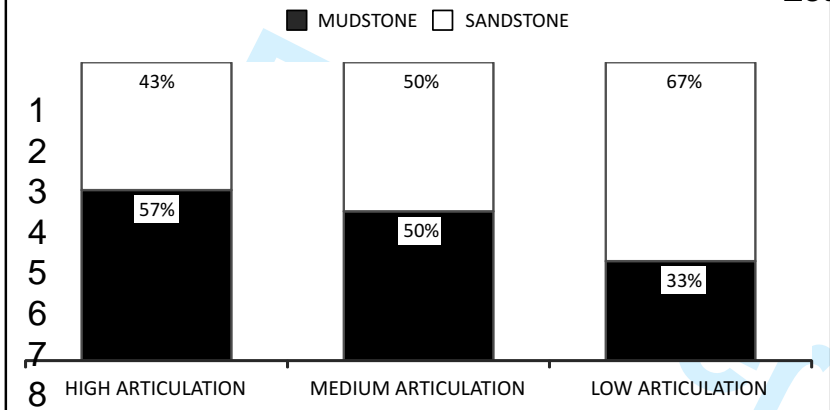

Bo ARTICULATION $v$ SKELETAL COMPLETENESS

$11 \square$ HIGH COMPLETENESS $\square$ LOW COMPLETENESS

12

13

13

14

15

16

17

18

19

20HIGH ARTICULATION

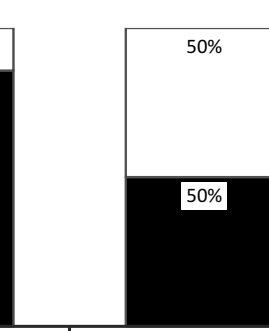

MEDIUM ARTICULATION

LOW ARTICULATION
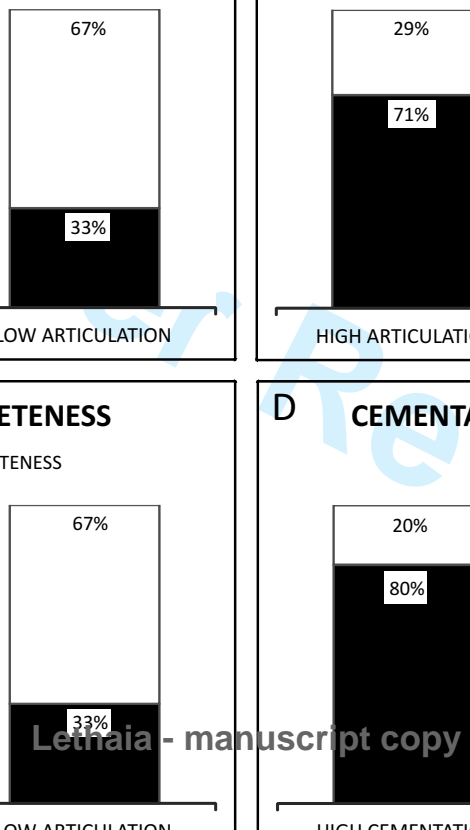

HIGH ARTICULATION

MEDIUM ARTICULATION

D CEMENTATION vs CORTICAL BONE PRESERVATION

$\square$ C.B. HIGH $\square$ C.B. MEDIUM $\square$ C.B. LOW
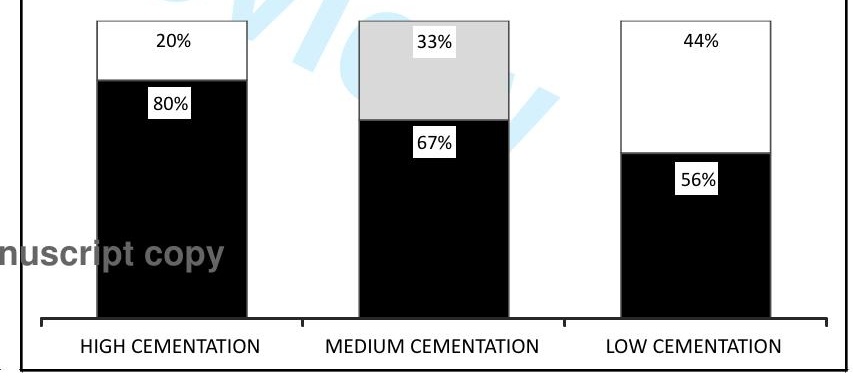

ARTICULATION vs SHARK TEẸHge $\mathbf{3 4}$ of $\mathbf{4 2}$
PRESENT $\square$ ABSENT

$56 \%$

$44 \%$ 


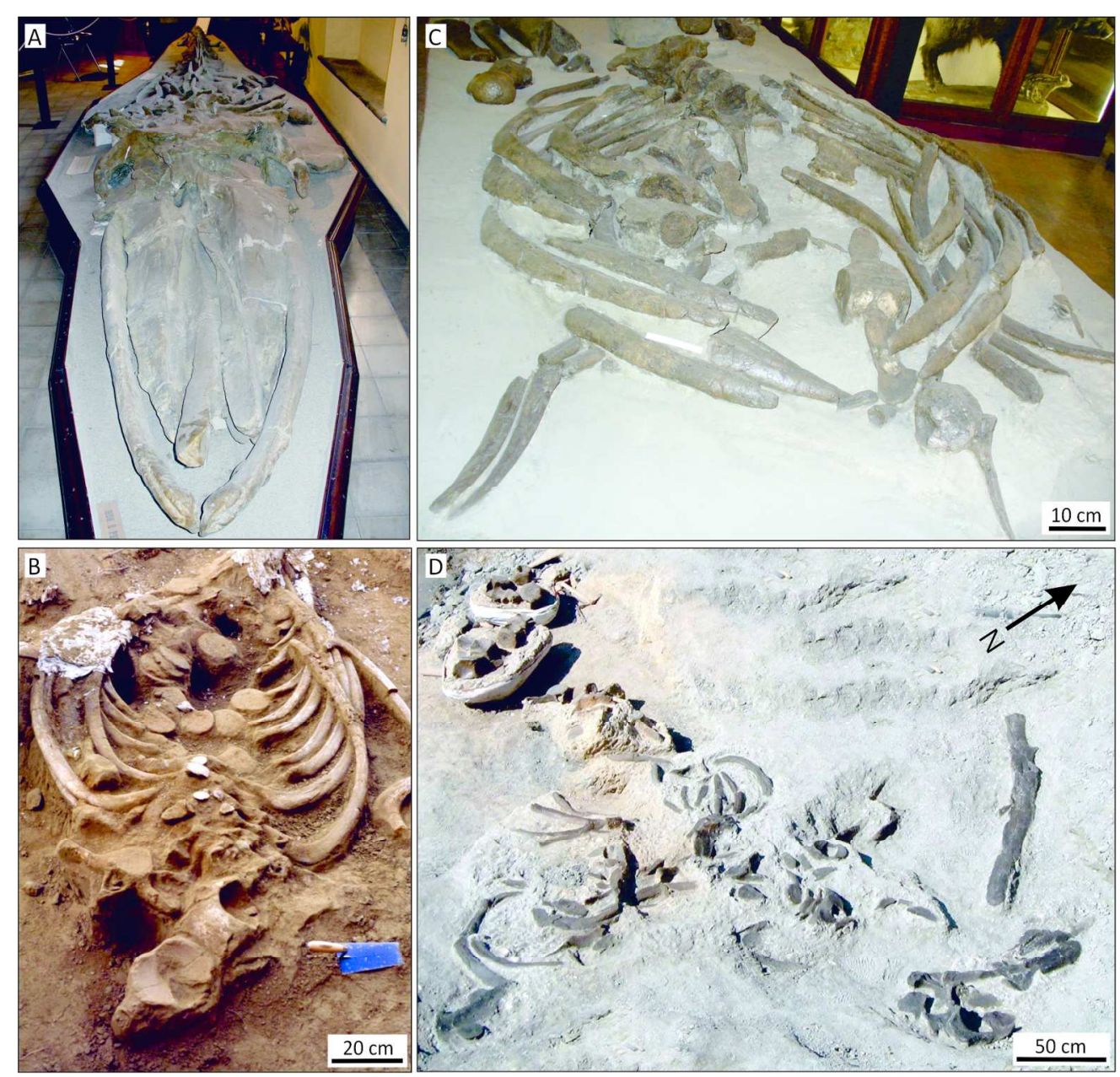

$170 \times 163 \mathrm{~mm}(300 \times 300 \mathrm{DPI})$ 

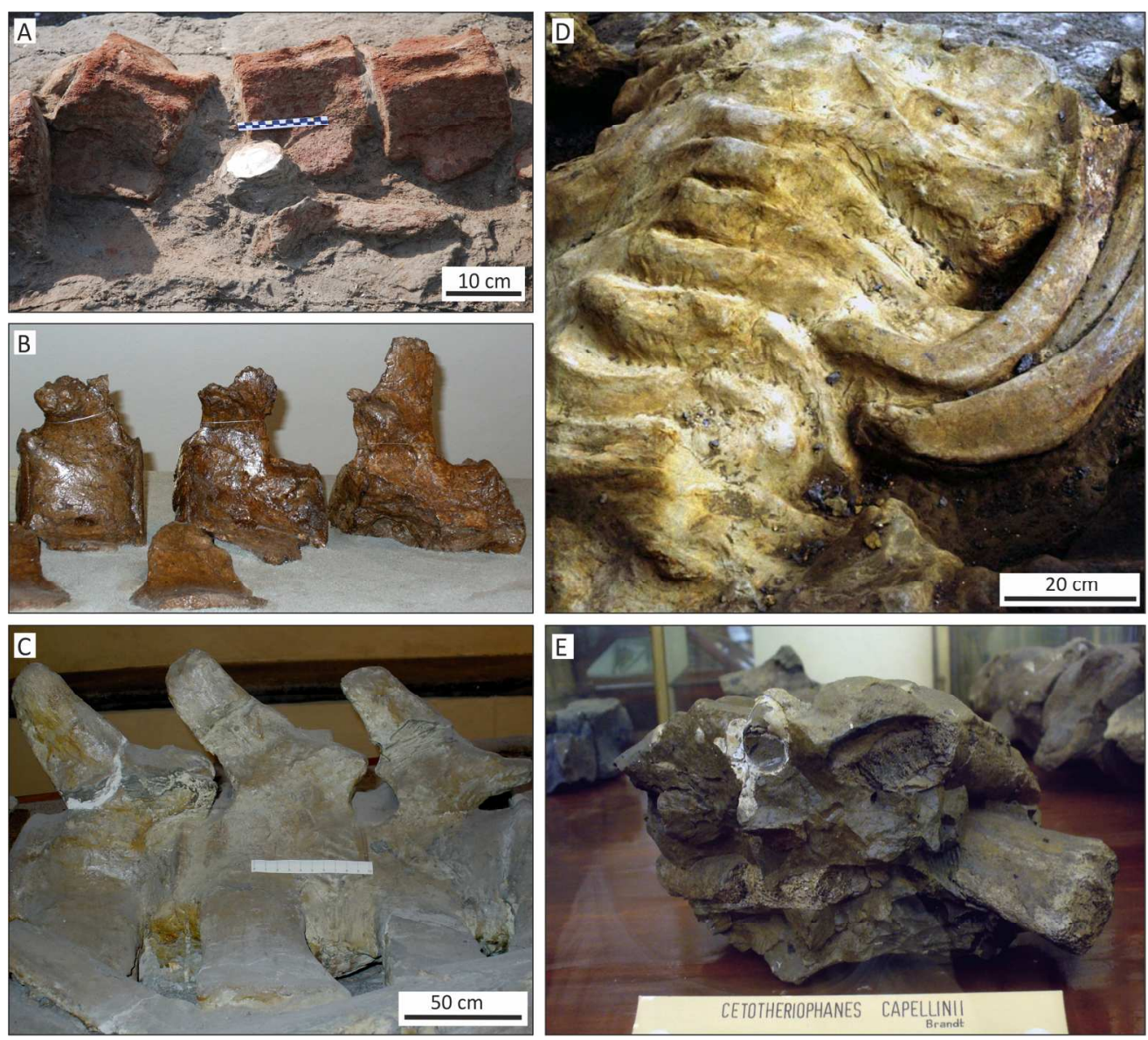

$170 \times 153 \mathrm{~mm}(300 \times 300 \mathrm{DPI})$

39

40

41

42

43

44

45

46

47

48

49

50

51

52

53

54

55

56

57

58

59

60 

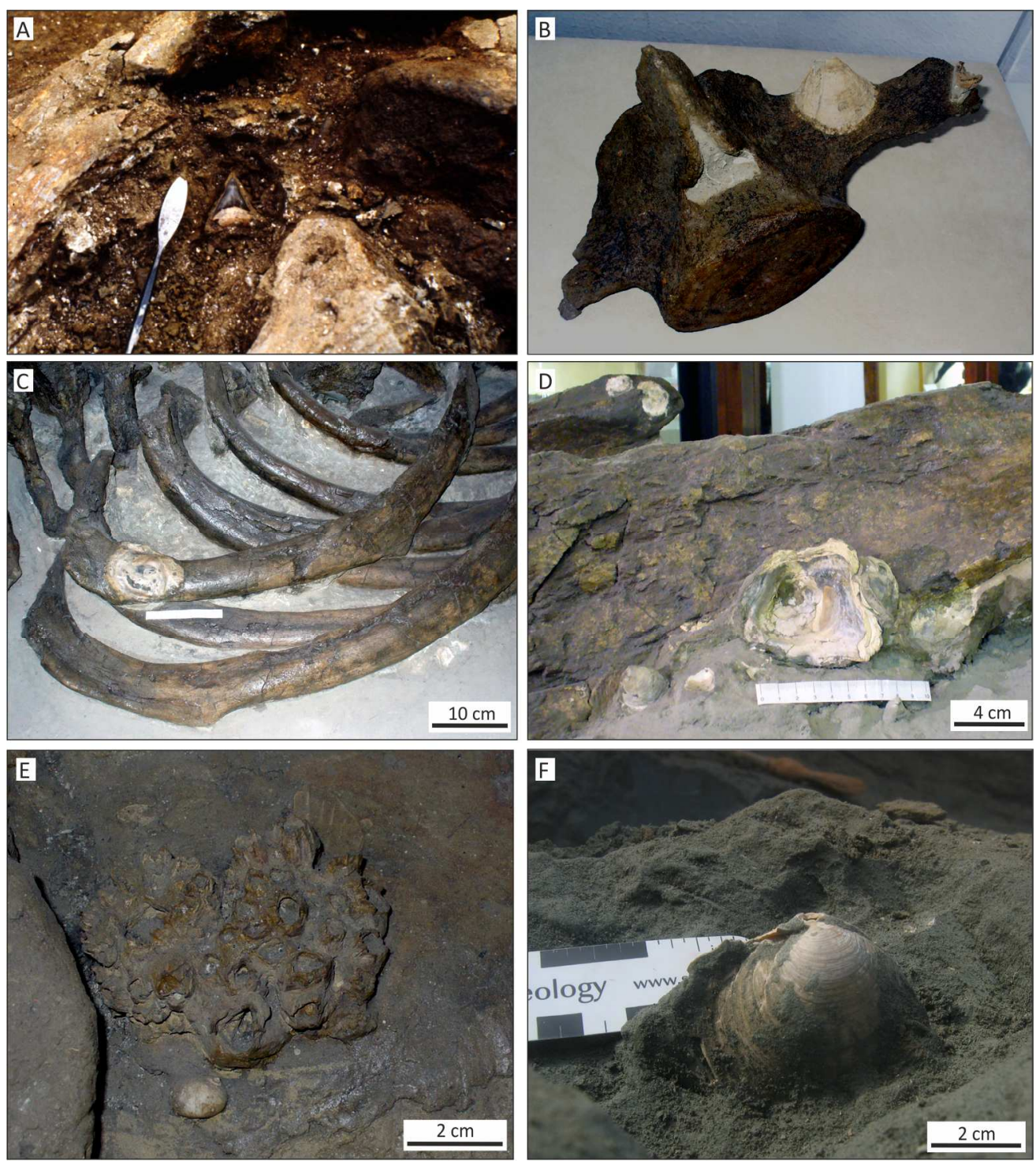

$170 \times 190 \mathrm{~mm}(300 \times 300$ DPI $)$ 


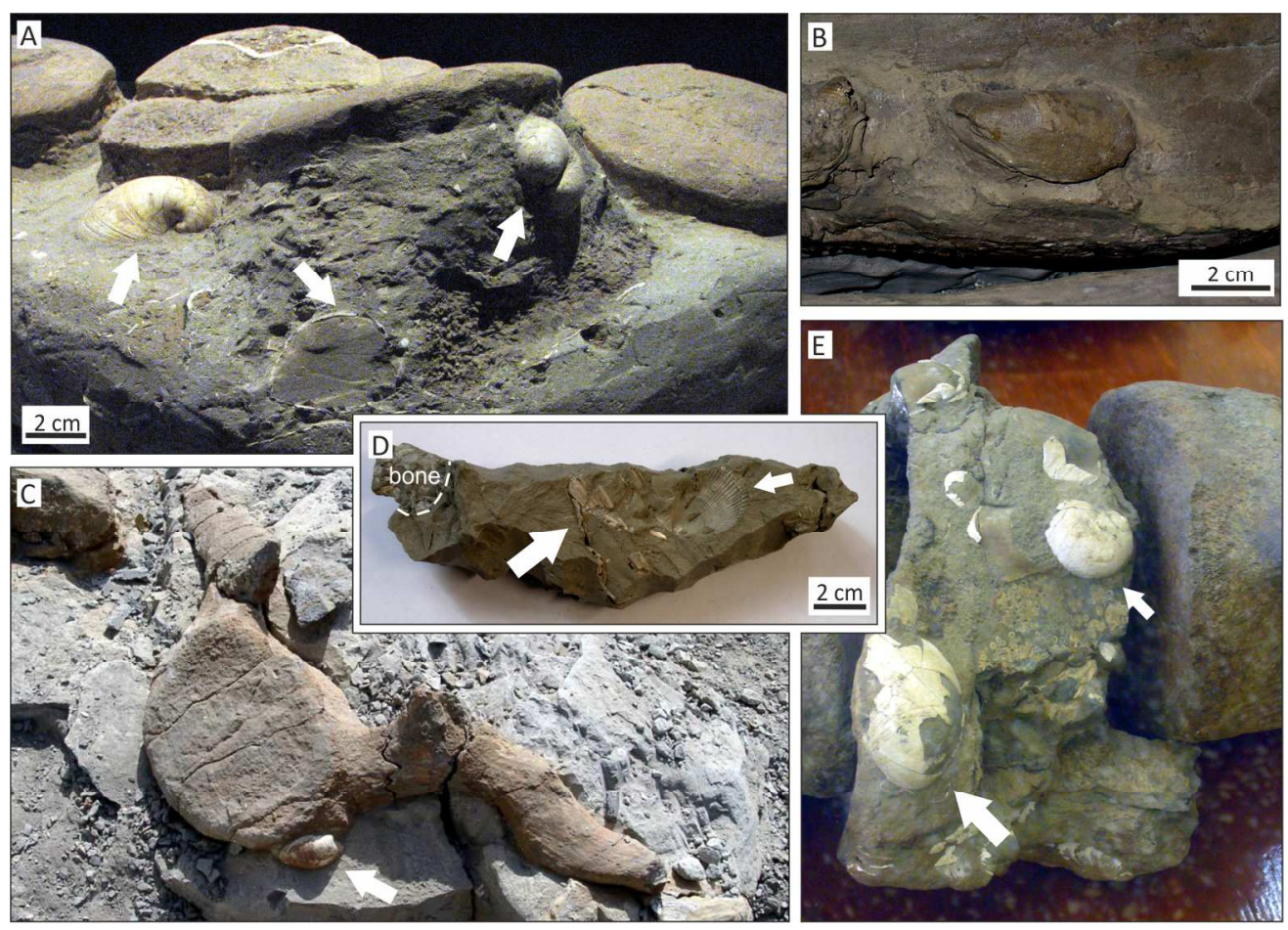

$170 \times 122 \mathrm{~mm}(300 \times 300 \mathrm{DPI})$ 


\section{Table 1}

Information on the studied Neogene fossil whales. Hosting institution abbreviation and taphonomic variable explained in the text.

Among incomplete skeletons, * indicates acephalous specimens, " indicates specimens that conserve only the skull.

\begin{tabular}{|c|c|c|c|c|c|c|c|c|c|c|c|c|c|c|c|}
\hline 莺 & $\grave{z}$ & 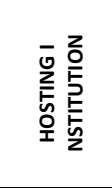 & 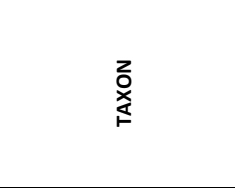 & $\begin{array}{l}\vdots \\
0 \\
0 \\
\vdots\end{array}$ & 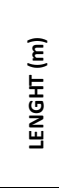 & 㷇 & 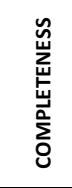 & 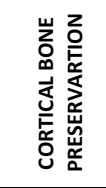 & 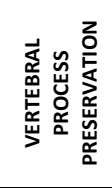 & 岁 & 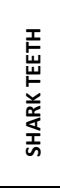 & 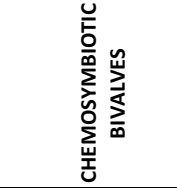 & 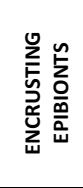 & 崖 & 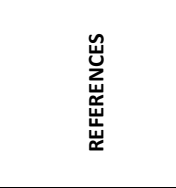 \\
\hline $\begin{array}{l}\text { Orciano Pisano } \\
\text { (PI) }\end{array}$ & W1 & MSNF & Mysticete & $\begin{array}{l}\text { Silty -fine } \\
\text { grained } \\
\text { sandstone }\end{array}$ & 10 & high & high & low & low & medium & yes & $\begin{array}{l}\text { Lucinidae, } \\
\text { Bathymodiolinae }\end{array}$ & yes & see Danise et al. 2010 & $\begin{array}{l}\text { Dominici et al. } \\
\text { 2009, Danise et } \\
\text { al. } 2010\end{array}$ \\
\hline $\begin{array}{l}\text { Vigliano d'Asti } \\
\text { (AT) }\end{array}$ & W2 & MGPT & $\begin{array}{l}\text { Balaenoptera } \\
\text { acutorostrata }\end{array}$ & $\begin{array}{l}\text { Silty fine- } \\
\text { grained } \\
\text { sandstone }\end{array}$ & 8 & high & high & high & high & medium & no & n.d. & yes & n.d. & $\begin{array}{l}\text { Caretto 1970, } \\
\text { Dominici et al. } \\
2009\end{array}$ \\
\hline $\begin{array}{l}\text { San Marzanotto } \\
\text { (AT) }\end{array}$ & w3 & MPSC & $\begin{array}{l}\text { Balaenoptera } \\
\text { acutorostrata }\end{array}$ & Mudstone & 8 & low & low & high & high & low & yes & n.d. & yes & $\begin{array}{l}\text { Carnivores (Nassarius italicus), } \\
\text { suspension feeders (Amusium } \\
\text { cristatum, Atrina pectinata, } \\
\text { Anadara diluvii, Pelecyora } \\
\text { brocchii, Neopicnodonte } \\
\text { cochlear), deposit feeders } \\
\text { (Aporrhais uttingeriana, } \\
\text { Tellina compressa) and } \\
\text { browsing carnivores } \\
\text { (Epitonium turtoni) } \\
\end{array}$ & $\begin{array}{l}\text { Damarco 1995, } \\
\text { Dominici et al. } \\
2009\end{array}$ \\
\hline $\begin{array}{l}\text { Portacomaro } \\
\text { d'Asti (AT) }\end{array}$ & W4 & MSNT & Balaenula astensis & $\begin{array}{l}\text { Silty fine- } \\
\text { grained } \\
\text { sandstone }\end{array}$ & 6 & medium & low" & high & n.d. & medium & no & n.d. & no & n.d. & $\begin{array}{l}\text { Trevisan 1941, } \\
\text { Dominici et al. } \\
2009\end{array}$ \\
\hline $\begin{array}{l}\text { Castell'Arquato } \\
\text { (PC) }\end{array}$ & W5 & MPP & $\begin{array}{l}\text { Balaenoptera } \\
\text { acutorostrata }\end{array}$ & Mudstone & 8 & high & high & high & medium & high & no & n.d. & yes & $\begin{array}{l}\text { Carnivores (Naticidae), } \\
\text { suspension feeders (Mytilidae, } \\
\text { Pectinidae) }\end{array}$ & $\begin{array}{l}\text { Strobel 1881, } \\
\text { Dominici et al. } \\
2009\end{array}$ \\
\hline $\begin{array}{l}\text { Rio dei Carbonari } \\
\text {-Castell'Arquato } \\
\text { (PC) }\end{array}$ & w6 & MGC & $\begin{array}{l}\text { Archaebalaenoptera } \\
\text { castriarquati }\end{array}$ & $\begin{array}{l}\text { Silty fine- } \\
\text { grained } \\
\text { sandstone }\end{array}$ & 7 & high & low" & high & n.d. & low & yes & n.d. & yes & n.d. & $\begin{array}{l}\text { Bisconti 2007, } \\
\text { Dominici et al. } \\
\text { 2009, Lo Russo } \\
\text { and Miti pers. } \\
\text { comm. }\end{array}$ \\
\hline $\begin{array}{l}\text { Rio Stramonte - } \\
\text { Castell'Arquato } \\
\text { (PC) }\end{array}$ & W7 & $\begin{array}{l}\text { No longer } \\
\text { available }\end{array}$ & $\begin{array}{l}\text { Balaenoptera } \\
\text { acutorostrata }\end{array}$ & Mudstone & 7 & high & high & medium & high & low & yes & n.d. & yes & n.d. & $\begin{array}{l}\text { Cortesi 1819, } \\
\text { Dominici et al. } \\
2009\end{array}$ \\
\hline $\begin{array}{l}\text { Rio Stramonte - } \\
\text { Castell'Arquato } \\
\text { (PC) }\end{array}$ & W8 & $\mathrm{MGC}$ & Mysticete & Mudstone & n.d. & n.d. & low* & n.d. & n.d. & n.d. & no & n.d. & no & $\begin{array}{l}\text { Suspension feeders (Glossus } \\
\text { humanus) }\end{array}$ & $\begin{array}{l}\text { Lo Russo and Miti } \\
\text { pers. comm. }\end{array}$ \\
\hline $\begin{array}{l}\text { Monte Falcone - } \\
\text { Castell'Arquato } \\
\text { (PC) }\end{array}$ & w9 & MGC & $\begin{array}{l}\text { Balaenoptera } \\
\text { acutorostrata }\end{array}$ & Mudstone & n.d. & low & high & high & low & medium & no & n.d. & no & n.d. & Francou 1994 \\
\hline $\begin{array}{l}\text { Monte Falcone - } \\
\text { Castell'Arquato } \\
\text { (PC) }\end{array}$ & W10 & MPP & Cettotherium capellinii & Sandstone & 9 & medium & low* & low & n.d. & medium & no & n.d. & no & n.d. & Scabelli 1843 \\
\hline
\end{tabular}




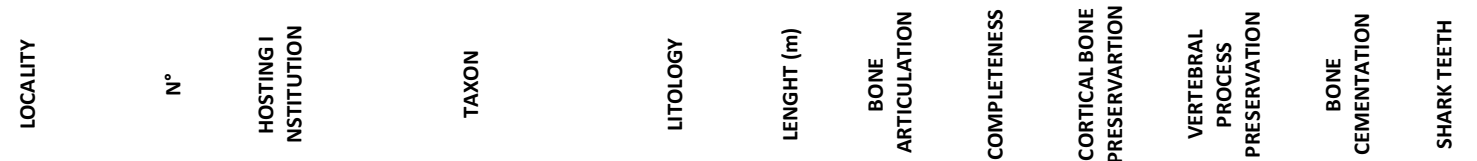
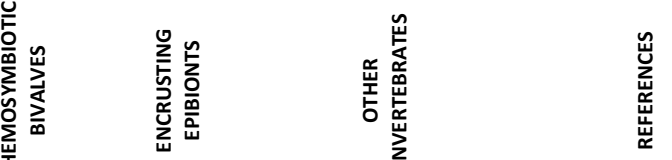

\begin{tabular}{|c|c|c|c|c|c|c|c|c|c|c|c|c|c|c|c|}
\hline $\begin{array}{l}\text { Monte La Ciocca - } \\
\text { Castell'Arquato } \\
\text { (PC) }\end{array}$ & W11 & MGC & Balaenoptera sp. & $\begin{array}{l}\text { Muddy } \\
\text { sandstone }\end{array}$ & n.d. & low & low & medium & medium & low & no & n.d. & no & n.d. & $\begin{array}{l}\text { Lo Russo and Miti } \\
\text { pers. comm. }\end{array}$ \\
\hline $\begin{array}{l}\text { Montezago, } \\
\text { Luganano Val } \\
\text { D'Arda (PC) }\end{array}$ & W12 & MPP & Megaptera sp. & Sandstone & 12 & low & low* & medium & low & low & no & n.d. & no & n.d. & Cortesi 1819 \\
\hline $\begin{array}{l}\text { Montezago, } \\
\text { Luganano Val } \\
\text { D'Arda (PC) }\end{array}$ & W13 & MPP & $\begin{array}{l}\text { Balaenoptera } \\
\text { acutorostrata }\end{array}$ & Mudstone & 4 & medium & high & high & high & high & no & n.d. & no & n.d. & Cortesi 1819 \\
\hline Gorgognano (BO) & W14 & MGCB & $\begin{array}{l}\text { Balaenoptera } \\
\text { acutorostrata }\end{array}$ & Mudstone & 9 & medium & high & low & medium & medium & no & n.d. & yes & $\begin{array}{l}\text { Suspension feeders (Mytilus } \\
\text { sp.); deposit feeders (Antalis } \\
\text { sp., Aporrhais uttingeriana } \\
\text { uttingeriana), carnivores } \\
\text { (Ficus sp.) }\end{array}$ & $\begin{array}{l}\text { Sarti and Gasparri } \\
\text { 1996, Dominci et } \\
\text { al. } 2009\end{array}$ \\
\hline $\begin{array}{l}\text { San Lorenzo in } \\
\text { Collina (BO) }\end{array}$ & W15 & MGCB & $\begin{array}{l}\text { Balaenoptera } \\
\text { acutorostrata }\end{array}$ & $\begin{array}{l}\text { Silty -fine } \\
\text { grained } \\
\text { sandstone }\end{array}$ & 8 & low & low & high & low & medium & yes & n.d. & yes & $\begin{array}{l}\text { Suspension feeders (Pelecyora } \\
\text { brocchi?, Venus } \\
\text { multilamella?), carnivores } \\
\text { (Naticidae) }\end{array}$ & $\begin{array}{l}\text { Capellini 1865, } \\
\text { Dominici et al. } \\
2009\end{array}$ \\
\hline Castellarano (RE) & W16 & MCRE & Balaena sp. & $\begin{array}{l}\text { Silty fine } \\
\text { grained } \\
\text { sandstone }\end{array}$ & 10 & low & low & high & high & medium & yes & n.d. & yes & $\begin{array}{l}\text { Suspension feeders } \\
\text { (Glycymeris inflata, Modiolus } \\
\text { sp., Ostrea sp.), scavengers } \\
\text { (decapods) }\end{array}$ & $\begin{array}{l}\text { Chicchi and } \\
\text { Scacchetti 2001, } \\
\text { Dominici et al. } \\
2009\end{array}$ \\
\hline Ponte a Elsa (PI) & W17 & MSNF & Balaena sp. & Mudstone & 10 & high & high & high & n.d. & high & yes & n.d. & no & $\begin{array}{l}\text { Suspension feeders (Chlamys } \\
\text { opercularis), deposit feeders } \\
\text { (Aporrhais uttingeriana, } \\
\text { Dentalium fossile), scavengers } \\
\text { (decapods) }\end{array}$ & $\begin{array}{l}\text { Borselli and } \\
\text { Cozzini 1992, } \\
\text { Dominici et al. } \\
2009\end{array}$ \\
\hline $\begin{array}{l}\text { Castel San } \\
\text { Gimignano (PI) }\end{array}$ & W18 & MSNF & Balaenoptera sp. & Sandstone & 8 & medium & low* & high & high & low & no & n.d. & no & n.d. & $\begin{array}{l}\text { Dominici et al. } \\
2009\end{array}$ \\
\hline Montopoli (PI) & W19 & MCPG & Eubalena sp. & $\begin{array}{l}\text { Very fine- } \\
\text { silty } \\
\text { sandstone }\end{array}$ & n.d. & n.d. & low & medium & n.d. & n.d. & yes & n.d. & no & n.d. & Bisconti 2002 \\
\hline Montopoli (PI) & W20 & MSNF & Idiocetus guicciardinii & $\begin{array}{l}\text { Sandy } \\
\text { mudstone }\end{array}$ & n.d. & n.d. & high & high & high & low & no & n.d. & no & $\begin{array}{l}\text { Carnivores (Naticidae, } \\
\text { Nassaridae), suspension } \\
\text { feeders (Pectinidae) }\end{array}$ & Capellini 1905 \\
\hline $\begin{array}{l}\text { Castelfiorentino } \\
\text { (FI) }\end{array}$ & W21 & MSNF & Balaenoptera sp. & Mudstone & 8 & high & high & medium & medium & high & yes & n.d. & yes & $\begin{array}{l}\text { Suspension feeders } \\
\text { (Mytilidae, Pectinidae) }\end{array}$ & $\begin{array}{l}\text { Dominici et al. } \\
2009 \text {, this study }\end{array}$ \\
\hline Montalcino (SI) & W22 & CVB & Balaenoptera sp. & $\begin{array}{l}\text { Silty -fine } \\
\text { grained } \\
\text { sandstones }\end{array}$ & 10 & low & high & high & high & low & yes & n.d. & no & n.d. & $\begin{array}{l}\text { Dominici et al. } \\
2009\end{array}$ \\
\hline Allerona (TR) & W23 & MCGA & Balaenula sp. (juvenile) & Mudstone & 2.5 & low & high & medium & low & low & no & n.d. & no & n.d. & This study \\
\hline Allerona (TR) & W24 & MCGA & Mysticete & Mudstone & 12 & medium & high & high & medium & medium & no & n.d. & yes & $\begin{array}{l}\text { Suspension feeders (Pelecyora } \\
\text { brocchi?) }\end{array}$ & This study \\
\hline Cà del Monte (PV) & W25 & CMSNV & Mysticete & $\begin{array}{l}\text { Fine grained } \\
\text { sandstone }\end{array}$ & n.d. & low & low & high & medium & high & no & n.d. & no & n.d. & $\begin{array}{l}\text { Danise et al. } \\
2013\end{array}$ \\
\hline
\end{tabular}




\section{Page 41 of 42}

\section{Lethaia}

1

2
3

5

7

8

9
10

12

13

14

15

16
17

18

18
19

20

21

22

23

25

26

27
28

29

30

31

32

33

34

35

36

37

38

39

40

41

42

43

44

45

47

48 


\begin{tabular}{l|l|l}
\hline a & Bone articulation & high, medium, low \\
\hline b & Completeness of the skeleton & high, low \\
\hline $\mathrm{c}$ & Cortical bone preservation & high, medium, low \\
\hline $\mathrm{d}$ & Vertebral process preservation & high, medium, low \\
\hline $\mathrm{e}$ & Bone cementation & high, medium, absent \\
\hline BIOTA ASSOCIATED WITH THE BONES & \\
\hline $\mathrm{f}$ & Shark teeth & present, absent \\
\hline $\mathrm{g}$ & Chemosymbiotic bivalves & present, absent, n.d. \\
\hline $\mathrm{h}$ & Encrusting epibionts & present, absent \\
\hline $\mathrm{i}$ & Other invertebrates & present, absent, n.d. \\
\hline
\end{tabular}

Table 2. List of the main taphonomic and paleoecologic variables considered in this study. 